\title{
言侖 文
}

\section{テレビゲームが子どもの攻撃行動および向社会的行動に及ぼす影響 一小学生意対象にし允パネル研究一}

\author{
井堀 宣子 ${ }^{\dagger}$ 坂元 章 ${ }^{\ddagger}$ 啮谷 明子 $^{\dagger}$ 湯川 進太郎 ${ }^{\ddagger}$ \\ †抢茶の水女子大学大学院人間文化研究科 $=112-8610$ 東京都文京区大塚2-1-1 \\ 拈茶の水女子大学大学院人間文化創成科学研究科 $7112-8610$ 東京都文京区大塚2-1-1 \\ ${ }^{\dagger}$ 慶應義塾大学メディア・コミュニケーション研究所テ108-8345 東京都港区三田2-15-45 \\ 筑波大学大学院人間総合科学研究科 $\bar{T} 112-0012$ 東京都文京区大塚3-29-1 \\ E-mail: ${ }^{\dagger} n \_$ihori07@hotmail.com
}

\begin{abstract}
概要 テレビゲームが子ど屯に与える影響を調べるため、小学生を対象にしたパネル研究を実施した。 調查を 2 回実施し、子どあのテレビゲーム使用量、シーン別接触量、ゲーム嗜好を測定するとともに、 攻撃行動、向社会的行動を測定した。交差遅れ効果モデルを用いて構造方程式モデル分析を行った結果、 男子において、平日のテレビゲーム使用量が多いほど、向社会的行動が抑制される傾向があった。また、 被調查者全体と男子に扔いて、向社会的シーンに接触する機会が多いほど、そして、非暴力ゲーム嗜好 が強いほど向社会的行動が促され、暴力ゲーム喍好が強いほど向社会的行動が抑制される傾向があった。 キーワード テレビゲーム, 攻撃行動, 向社会的行動, パネル研究
\end{abstract}

\section{1. 問題}

これまで「暴力的なテレビゲームで遊ぶと攻撃性や 攻撃行動が増加するか?」ということをテーマに、さ

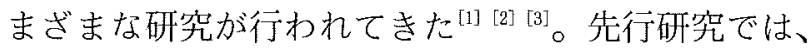
夹験研究、調查研究、パネル研究の3つのパターンが あり、そ机ぞれに扔いてテレビゲーム使用が攻撃性、 攻撃行動に及ぼす悪影響を示唆する結果がしばしば出 されている。

実験室実験は、実験室において、実験群の被験者に 攻擊型のテレビゲームで遊ばせ、その後の攻撃性を、 対照群のそれと比較することによって、テレビゲーム 使用の影響を調べるものである。実験室実験は一般に、 因果関係の特定にあたって強力であるむのの、その実 験場面の人工性や、因果関係が特定できるとは言って 屯短期的な屯のにほぼ限られる点に問題がある。

一方、調査研究では、被調查者のテレビゲーム使用 量と攻撃性を測定し、画者の相関を検討する。いくつ かの研究で使用量と攻撃性の間に有意な正相関が得ら れているが ${ }^{[4]}[5]$ [6]、一時点での調査では、そうした相 関が認めら狆ても、どちらが原因で、どちらが結果か については言及できない。したがって調查研究では、
実験研究の人工性の問題を克服するが、因果関係を特 定することができない。

しかし、調査研究であっても、パネル研究の手法を 用い狆ば、これまでの一時点での相関を求めてきた手 法より屯、因果関係に近づくことがある程度可能であ る ${ }^{[7]}$ 。パネル研究とは、同一の被験者に対して同一の 変数を複数回湘定する調査研究である。この万法で得 られたデー夕を分析することによって因果関係を推定 できる。

筆者らは、こうしたパネル研究を以前からしばしば 行って抬り Gentile, \& Buckley の研究 ${ }^{[1]}$ が出されているが、依 然として、テレビゲームの影響については、パネル研 究はあまり行われて抢らず、その報告ああまり見られ ない。そこで、本稿では、筆者たちが行った未公刊の パネル研究の結果を報告する。

筆者らのこれまでのパネル研究では、テレビゲーム 使用量の変数として、主にテレビゲーム全体や各ジャ

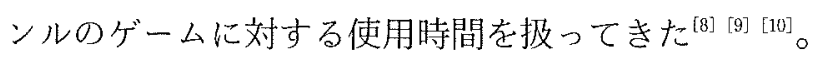
本研究ではそれに加えて、とくに暴力的なシーンに刘 する使用時間を测定するとともに、使用量を反映しう 
る指標として、暴力的なゲームへの睹好性を报ってい る。使用時間はその人が置かれている状況によって変 化するが、嗜好性にはこのような変化があまりなく、 時間的に安定していると見られる点でメリットがある。 また、テレビゲーム使用によって影響されうる心理 的側面として、攻撃行動とと屯に向社会的行動につい ても検討している。以前より、暴力的テレビゲーム使 用と向社会的行動の間には負の相関関係があることが

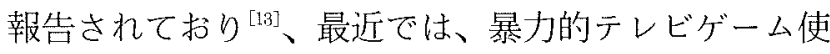
用が向社会的行動を抑制するという因果関係走示唆す

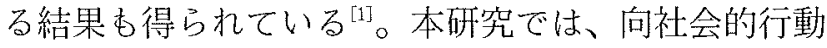
屯报うことによって、これを確認するあのとなってい る。

さらに、本研究では、暴力シーンだけでなく、向社 会的シーンに対する接触量など屯調べており、それが 向社会的行動学促すかどうか子検討している。従来、 テレビに関する研究では、暴力シーン接触が攻撃行動 老促す一方で、向社会的シーンが向社会的行動を促す ことが示されて招り ${ }^{[14][15] 、 テ レ ヒ ゙ ケ ゙ ー ム て ゙ あ 、 こ れ ~}$ と同様のことが起こるかどうかの娭討となっている。

\section{2. 方法}

\section{1 被調查者}

被調査者は、以下の手順で全国加らの無作為サンプ リングを行った。都市、地方の公立小学校から各 4 校、 計 8 校在無作為に抽出し、各校それぞれ 5 年生100名 〜150名程度を対象とした。1 回目の調査では900名が 回答し（回収率94.4\%）、2 回目の調査では903名が回 答した（回収率94.8\%）。このうち回答に不備のあっ た者を除き、2回の調査に回答した780名（男子384名、 女子396名）を分析の対象とした。

\section{2 調查時期と実施方法}

調查は 2 回実施した。1 回目は2001年11月～12月に、 2 回目は2002年 2月〜3月に実施した。

実施方法としては、担任の教員加らクラスの生徒に 質問紙亡封筒を配布して屯らい、その場で各自が記入 した上で封筒に入れ、提出するように指示してもらっ た。また、実施の際、調查の趣旨、回答者には一切迷
惑をかけないこと、教員は生徒の回答を見ないことを 説明してもらった。

\section{3 調查内容}

\subsection{1 テレビゲーム使用量の测定}

最近 1 ケ正、1 週間に何日くらいテレビゲームで 遊んだかについて、日数で測定した。まったく遊ばな かった場合は「0」、3日の場合は「3」のように回答 させた。また、同様に最近 1 ケ月で、1 日におよそ何 時間テレビゲームで遊んだかについて、平日（学校の 授業のある日）亡土日（授業のない日）にわけて测定 した。全く遊ばなかった場合は「0」、30分の場合は $\lceil 0.5\rfloor 2$ 時間の場合は「2」のように回答させた。

\subsection{2 接触シーンの测定}

最近 1 ヶ月の間、テレビゲームで遊んでいて見かけ たシーンについて、1（まったく見かけなかった）か ら5 (とてもよく見加けた）の5段階で回答させた。 シーンは、暴力シーン（5項目：「ことばでひどいこ と㕝言うシーン」銃でうったり剣で切ったりするシー ン」「人を殺すシーン」「殴ったり蹴ったりするシーン」 「ロボットや飛行機の戦闘シーン」)、向社会的シーン （2項目：「困っている人を助けるシーン」「友情や親 子のつながりを確かめ合うシーン」)、性的シーン（1 項目：「キスしたり男女が抱き合ったりするシーン」） の3 種類のシーンが含まれていた。

\subsection{3嗜好ゲームのジャンルの測定}

テレビゲームの中での好きなジャンルについて、暴 力的ゲーム（2 項目：戦って相手を倒すゲーム、戦い ながら物語を進めていくゲーム)、非暴力的ゲーム （4項目：スポーツやレースのゲーム、本物とそっく りの場面孛体験するゲーム、パズル、音楽ゲーム）加 ら最も好きなあのを1つ、そ机以外で好きなむのを数 を限らず選択させた。

\subsection{4 攻撃行動と向社会的行動の測定}

最近 1 ヶ月の間に起こした攻撃行動と向社会的行動 について尺度を作成し、1（まったくなかった）から 5 （とてもよくあった）の5段階で評定させた。項目 は、攻撃行動では「人を殴る加蹴るかした」「人がやっ たことに腹を立てた」「人に口で文句をいった」「人の 
やることに嫌な感じがした」であり、向社会的行動で は「困っている人を助けた」「人に優しくした」「白分 の好きなこと索いっしょうけんめいした」「人のため になることをした」であった。

\subsection{5 社会的望ましさの测定}

項目に対する回答の妥当性を検討するために、社会 的に望ましい回答をする傾向を、桜井（1984） ${ }^{[16]}$ の児 童用社会的望ましさ测定尺度（SDSC）で、1（はい）、 2 (いいえ) の2段階で測定した。なお、社会的望ま しさに関しては 1 回目でのみ測定した。

\subsection{6 その他}

以上の他に、被調查者には、性别、年齡、学年、組、 出席番号を尋放た。また、質問紙にある漢字のほと九 どにはルビを振っていた。

\section{3. 結果}

\section{1 各変数の平均}

\section{1 .1 テレビゲーム使用量}

テレビゲームを使用した 1 週間あたりの日数、また 平日、土日の使用時間の平均值算出した（表 1 ）。 男子は 1 週間に 4 日以上、女子は 1 週間に 2 日以上テ レビゲームを使用しており、平日では男子は 1 時間以 上、女子は 1 時間未満、土日では男子は 2 時間以上、 女子は 1 時間以上使用していることがわかった。 1 週 間の使用日数、平日、土日の使用時間之屯に、男子の 方が女子より西有意に多かった。この結果は、1回目 と2回目の調査の間で一貫していた。

\section{1 .2 シーン別の接触量}

暴力シーン、向社会的シーン、性的シーンのそれぞ 机によ゙の程度接触したかについて平均值を算出した (表 2)。暴力シーンについては、1回目、2回目とあ に男子の方が女子より有意に多く接触していた。向 社会的シーンについては、男女で有意差は見られなかっ た。また、性的シーンについては、2回目において女 子の方が男子よりも有意に多く接触していた。

\subsection{3 嗜好ゲームのジャンル}

表 3 に、搘好されているジャンルに関する集計結果 を示す。1回目に括いて好きなジャンルで多かったの は、「䦥って相手を倒すゲーム（暴力ゲーム）」であり、
次に「スポーツやレースのゲーム（非暴力ゲーム）、、 「闘いながら物語を進めていくゲーム（暴力ゲーム）」 が続いた。最も好きなジャンルで多かったのは、闘っ て相手を倒すゲーム（暴力ゲーム）」であった。さら に、2回目において好きなジャンルで多かったのあ、 「䦔って相手を倒寸ゲーム（暴力ゲーム）」であり、次 に「パズル (非暴力ゲーム)」、闘いながら物語を進 めていくゲーム (暴力ゲーム)」「スポーツやレース のゲーム（非暴力ゲーム）」が続いた。また、最も好 きなジャンルで多かったのは、1回目と同様、「闘っ て相手を倒すゲーム（暴力ゲーム）」であった。1回 日、2回日と杂に、「䦥って相手索倒すゲーム（暴力 ゲーム)」は好きなジャンルであ、最も好きなジャン ルでも多かった。この結果から、小学生が好むゲーム は暴力的なむのが多いと言える。

次に、「好き」存 1 点、「最屯好き」を2点として、 暴力ゲームを嗜好する程度（闘って相手を倒すゲーム、 闘いながら物語を進めていくゲーム)、非暴力ゲーム を搘好する程度（スポーツやレースのゲーム、本物と そっくりの場面を体験するゲーム、パズル、音楽ゲー ム）を算出した（表 4)。ここから、1回目、2 回目 ともに、男子の方が女子より屯暴力ゲームを有意に好 み、女子の方が男子よりも非暴力ゲームを好むことが 確認された。

\section{1 .4 攻撃行動および向社会的行動}

各項目の平均評定值を攻撃行動㧍よび向社会的行動 の得点しし、その平均值を算出した（表 5 ）。また、 この質問項目は独自作成したものであったため、信頼 性係数 $\alpha$ を算出するとともに、主成分分析在行った。 $\alpha$ 係数はよ゙ちらも.7以上であり、まずまずの信頼性 があることを示していた。また主成分分析の結果む、 各項目の負荷量がほほ．4以上、さらに第 2 主成分以 下は固有值がす心゙て 1 以下であったこよから、尺度項

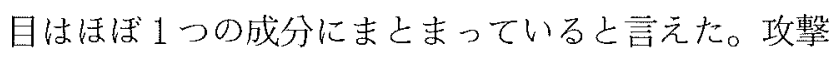
行動については男女で有意差は見られなかったが、向 社会的行動については女子の方が男子より古有意に得 点が高かった。この結果は1回目と2回目で一貫して いた。 
表 11 週間の使用日数と平日・土日の使用時間

\begin{tabular}{|c|c|c|c|c|c|c|c|c|c|}
\hline & & \multicolumn{4}{|c|}{1 回目 } & \multicolumn{4}{|c|}{2 回目 } \\
\hline & & 全体 & 男子 & 女子 & $t$ 值 & 全体 & 男子 & 女子 & $t$ 值 \\
\hline \multirow[t]{2}{*}{ 日 / 週 } & $M$ & 3.39 & 4.36 & 2.25 & $13.54^{\mathrm{kth}}$ & 3.51 & 4.42 & 2.43 & $12.69^{* * *}$ \\
\hline & $S D$ & $(2.28)$ & $(2.18)$ & $(1.83)$ & & $(2.21)$ & $(2.06)$ & $(1.88)$ & \\
\hline \multirow[t]{2}{*}{$\mathrm{h}$ /平日 } & $M$ & 1.18 & 1.59 & .68 & $7.48^{* *}$ & 1.36 & 1.67 & .98 & $3.49^{\circ *}$ \\
\hline & $S D$ & $(1.71)$ & $(2.01)$ & $(1.09)$ & & $(2.49)$ & $(2.23)$ & $(2.73)$ & \\
\hline \multirow[t]{2}{*}{$\mathrm{h} /$ 土日 } & $M$ & 2.15 & 2.76 & 1.43 & $8.09^{* *}$ & 2.29 & 2.76 & 1.72 & $4.64^{* *}$ \\
\hline & $S D$ & $(2.27)$ & $(2.41)$ & $(1.86)$ & & $(2.84)$ & $(2.34)$ & $(3.26)$ & \\
\hline
\end{tabular}

注 : ${ }^{* *} p<.01$

表 2 接触シーンごとの接触量

\begin{tabular}{|c|c|c|c|c|c|c|c|c|c|}
\hline & & \multicolumn{4}{|c|}{1 回目 } & \multicolumn{4}{|c|}{2 回目 } \\
\hline & & 全体 & 男子 & 女子 & $t$ 值 & 全体 & 男子 & 女子 & $t$ 值 \\
\hline \multirow[t]{2}{*}{ 暴カシーン } & $M$ & 2.58 & 3.01 & 2.07 & $10.83^{* *}$ & 2.56 & 2.90 & 2.15 & $8.56^{* *}$ \\
\hline & $S D$ & $(1.17)$ & $(1.13)$ & $(1.01)$ & & $(1.18)$ & $(1.18)$ & $(1.04)$ & \\
\hline \multirow[t]{2}{*}{ 向社会的シーン } & $M$ & 2.01 & 2.04 & 1.98 & .74 & 2.01 & 2.00 & 2.03 & -.45 \\
\hline & $S D$ & $(1.03)$ & $(1.03)$ & $(1.04)$ & & $(1.06)$ & $(1.05)$ & $(1.07)$ & \\
\hline \multirow[t]{2}{*}{ 性的シーン } & $M$ & 1.36 & 1.37 & 1.35 & .29 & 1.32 & 1.25 & 1.40 & $-2.41^{*}$ \\
\hline & $S D$ & $(.87)$ & $(.90)$ & $(.85)$ & & $(.78)$ & $(.70)$ & $(.87)$ & \\
\hline
\end{tabular}

注: $* p<.05, * * p<.01$

表 3 喍好されているジャンル

\begin{tabular}{|c|c|c|c|c|c|c|c|c|}
\hline & \multicolumn{4}{|c|}{1 回目 } & \multicolumn{4}{|c|}{2 回目 } \\
\hline & \multicolumn{2}{|c|}{ 好き } & \multicolumn{2}{|c|}{ 最も好き } & \multicolumn{2}{|c|}{ 好き } & \multicolumn{2}{|c|}{ 最も好き } \\
\hline & 度数 & 比率 & 度数 & 比率 & 度数 & 比率 & 度数 & 比率 \\
\hline 闘って相手を倒すゲーム & 321 & 44.09 & 184 & 25.27 & 346 & 47.59 & 195 & 26.82 \\
\hline 闣いながら物語を進めていくゲーム & 298 & 40.93 & 182 & 25.00 & 298 & 40.99 & 188 & 25.86 \\
\hline スポーツやレースのゲーム & 307 & 42.17 & 53 & 7.28 & 293 & 40.30 & 59 & 8.12 \\
\hline 本物とそっくりの場面を体験するグーム & 153 & 21.02 & 6 & .82 & 155 & 21.32 & 16 & 2.20 \\
\hline パズル & 289 & 39.70 & 76 & 10.44 & 314 & 43.19 & 68 & 9.35 \\
\hline 音楽ゲーム & 206 & 28.30 & 95 & 13.05 & 212 & 29.16 & 104 & 14.31 \\
\hline
\end{tabular}

注：52の無回答がある。 
表 4 暴力ゲーム・非暴力ゲームに対する㫮好

\begin{tabular}{|c|c|c|c|c|c|c|c|c|c|}
\hline & & \multicolumn{4}{|c|}{1 回目 } & \multicolumn{4}{|c|}{2 回目 } \\
\hline & & 全体 & 男子 & 女子 & $t$ 值 & 全体 & 男子 & 女子 & $t$ 值 \\
\hline \multirow[t]{2}{*}{ 暴力ゲーム喏好 } & $M$ & 1.86 & 2.30 & 1.39 & $11.96^{* *}$ & 1.94 & 2.37 & 1.50 & $11.71^{* * *}$ \\
\hline & $S D$ & (1.12) & (.95) & $(1.09)$ & & $(1.09)$ & $(.89)$ & $(1.10)$ & \\
\hline \multirow[t]{2}{*}{ 非暴力ゲーム㘃好 } & $M$ & 1.94 & 1.58 & 2.32 & $-7.55^{* *}$ & 2.02 & 1.59 & 2.46 & $-9.35^{* * *}$ \\
\hline & $S D$ & $(1.38)$ & $(1.26)$ & $(1.39)$ & & $(1.33)$ & $(.1 .27)$ & $(1.26)$ & \\
\hline
\end{tabular}

注 : $* * p<, 01$

表 5 攻揧行動・向社会的行動・社会的望ましさの得点

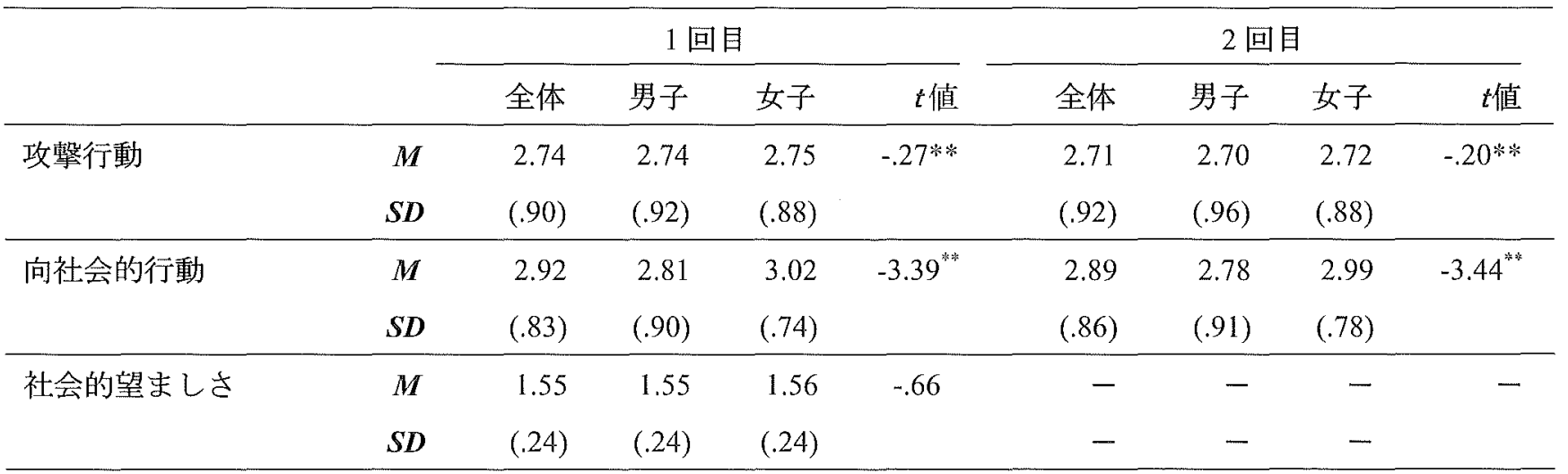

注 : ** $p<.01$

\section{2 因果関倸の検討}

本研究では一定の間隔（2〜4ヶ月）を空けて 2 回 の調查を行い、それぞれに扔いてテレビゲームの使用 に関する变数と、そ扎に影響されうる心理的側面の变 数（攻撃行動、向社会的行動）在測定した。一般に、 時間的に後にあるものは先に生じたものの原因になる ことはないと前提されよう。むし、1回目のテレビゲー ム変数之 2 回目の心理的変数の間に高い相関が見ら扎
れば、それは、2 回目の心理的変数が 1 回目のテレビ ゲーム変数に影響したことによるものとは解秎されず、 1 回目のテレビゲーム变数が 2 回目の心理的变数に影 響したことによる可能性が想定される。

因果の推定のため、交差遅れ効果モデルを用いた構 造方程式モデル分析を行った。なお分析では性別を統 制した。さらに社会的望ましさについてむ、心理的変 数との相関が高かったため、同様に統制した。

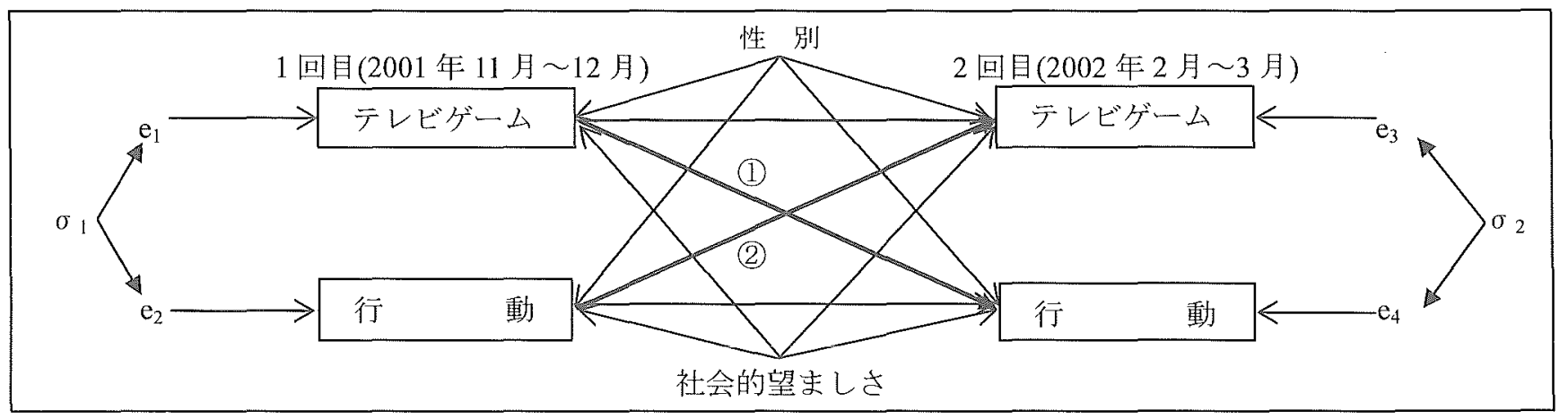

図 1 本研究の分析モデル 
これらの变数の統制のため、それらをモデルに組み 込んだことにより、分析モデルは最終的に図 1 のよう になった。2つの変数を組み込んだ結果、1回目のテ レビゲーム変数と、1 回目の攻撃行動・向社会的行動 が内生变数となり、そのため、䛊差の $\mathrm{e}_{1}$ 抢よび $\mathrm{e}_{2}$ よ、 これらの共分散 $\left(\sigma_{1}\right)$ を設定した。2 回目のテレビゲー 厶变数之 2 回目の攻撃行動・向社会的行動の䛊差はそ れぞれさ と为であり、これらの共分散は $\left(\sigma_{2}\right)$ である。 このモデルにテレビゲーム变数のそれぞれと、攻撃行 動あるいは问社会的行動の得点を 1 つずつモデルに投 入し、分析を行った。

本研究では、図 1 のモデルから派生する4つのモデ ルを比較した上で、最む適していると考えられるむの を採択し、最終的な結果を導いた。モデル 1 は、 $\sigma_{1}$ と $\sigma_{2}$ を雨方とあ開放して推定するモデルである。モ デル 1 は飽和モデルであり、最も制約が少ない。モデ ル 2 は $\sigma_{1}$ のみを開放し、 $\sigma_{2}$ を 0 に固定して推定する モデルである。逆にモデル 3 は $\sigma_{2}$ のみを開放し、 $\sigma_{1}$ を０に固定したモデルである。モデル４は両方の共分 散を０に固定して推定するモデルである。モデル 4 は 4 つのモデルの中で最む安定性の高いモデルである。 これら 4 つのモデルをカイ二乗値により比較し、とく に有意差がない場合は制約の多いモデルを選択した。

ここではまず 1 回目のテレビゲーム变数から 2 回目 の行動（攻撃行動あるいは向社会的行動）へのパスに 関する結果についてテレビゲーム変数ごとに報告する。

ここで正の効果が見られた場合、テレビゲーム变数 が高いほど攻撃行動、向社会的行動を増加させ、負の 効果が見られた場合、テレビゲーム变数が高いほど攻 撃行動、向社会的行動を減少させることを示唆する。

\subsection{1 ゲーム使用量から行動への影響（表 6 ）}

平日の使用時間から行動へのパスを検討した結果、 被調查者全体、女子では有意な効果は見られなかった。 男子のみで向社会的行動に有意な負の効果が見られた。 これは男子で平日の使用時間が多いと向社会的行動が 減少することを示している。

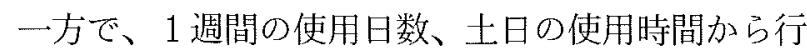
動へのパスを検討した結果、有意な効果は見られなかっ た。

\subsection{2 接触シーンから行動への影響（表 7）}

向社会的シーン接触から行動へのパスを検討した結 果、被調查者全体と男子で向社会的行動に有意な正の 効果が見られた。これは向社会的シーンに接触する機 会が多いよ、被調查者全体、男子では向社会的行動が 増加するということを示している。

一方で、暴力シーン、性的シーン接触から行動への パスを検討した結果、有意な効果は見られなかった。

\section{2 .3 ゲーム嗜好から行動への影響（表 8）}

暴力ゲーム嗜好から行動へのパスを検討した結果、 被調査者全体、男子では向社会的行動に有意な負の効 果が見られ、女子では有意な效果は見られなかった。 こ机は暴力的なゲームを好む程度が高いと、被調查者 全体、男子では向社会的行動が減少することを示して いる。

また、非暴力ゲーム嗜好から行動へのパスを検討し た結果、被調査者全体と男子で向社会的行動に有意な 正の効果が見られた。女子では有意な効果は見られな かった。これは非暴力的なゲームを好む程度が高いと、 被調查者全体と男子で向社会的行動が高まることを示 している。

\subsection{4 行動からテレビゲーム変数への影響（表 9)}

最後に、2 回目の行動から 1 回目のテレビゲーム変 数へのパス（図1の(2)）についてむまとめて報告する。

有意であったのは、いずれ屯向社会的行動からテレ ビゲーム变数への効果であった。まず使用時間につい て、女子のみで平日の使用時間に有意な正の効果が見 られた。これは女子で向社会的行動が多いと平日の使 用時間が増加することを示している。また、男子のみ で土曰の使用時間に有意な負の効果が見られた。これ は男子で向社会的行動が多いと土日の使用時間が減少 することを示している。

さらに、接触シーンについて、全体之男子で向社会 的シーンに有意な正の効果が見られた。これは向社会 的行動が多いと、向社会的シーンへの接触が増加する ことを示している。 
表 6 テレビゲーム使用量から行動への影響

\begin{tabular}{|c|c|c|c|c|c|c|c|c|c|c|c|c|}
\hline \multirow[b]{3}{*}{ 平日 } & \multicolumn{6}{|c|}{ 攻揧行動 } & \multicolumn{6}{|c|}{ 向社会的行動 } \\
\hline & \multicolumn{2}{|c|}{ 全体 } & \multicolumn{2}{|c|}{ 男子 } & \multicolumn{2}{|c|}{ 女子 } & \multicolumn{2}{|c|}{ 全体 } & \multicolumn{2}{|c|}{ 男子 } & \multicolumn{2}{|c|}{ 女子 } \\
\hline & -.01 & (4) & -.02 & (4) & .02 & (4) & -.07 & (4) & $-.10^{*}$ & (4) & .03 & (4) \\
\hline 土日 & -.01 & (3) & -.00 & (4) & -.01 & (3) & .01 & (2) & -.05 & (4) & .09 & (2) \\
\hline 1 週間 & .01 & (3) & .01 & (3) & .00 & (4) & .04 & (2) & .02 & (4) & .05 & (2) \\
\hline
\end{tabular}

注：カッコ内は選択したモデルを示す。

表 7 シーン接触量から行動への影響

\begin{tabular}{|c|c|c|c|c|c|c|c|c|c|c|c|c|}
\hline \multirow[b]{3}{*}{ 暴カシーン } & \multicolumn{6}{|c|}{ 攻撃行動 } & \multicolumn{6}{|c|}{ 向社会的行動 } \\
\hline & \multicolumn{2}{|c|}{ 全体 } & \multicolumn{2}{|c|}{ 男子 } & \multicolumn{2}{|c|}{ 女子 } & \multicolumn{2}{|c|}{ 全体 } & \multicolumn{2}{|c|}{ 男子 } & \multicolumn{2}{|c|}{ 女子 } \\
\hline & .06 & (1) & .03 & (1) & .10 & (1) & .01 & (2) & .04 & (4) & .00 & (4) \\
\hline 向社会的シーン & .04 & (1) & .02 & (3) & .08 & (2) & $.10^{* * *}$ & (2) & $.11^{*}$ & (2) & .09 & (1) \\
\hline 性的シーン & -.02 & (1) & -.02 & (4) & -.02 & (1) & .01 & (2) & -.02 & (4) & .05 & (2) \\
\hline
\end{tabular}

注：カッコ内は選択したモデルを示す。

表 8 ゲーム傄好から行動への影響

\begin{tabular}{|c|c|c|c|c|c|c|c|c|c|c|c|c|}
\hline \multirow[b]{3}{*}{ 暴力グーム } & \multicolumn{6}{|c|}{ 攻摮行動 } & \multicolumn{6}{|c|}{ 向社会的行動 } \\
\hline & \multicolumn{2}{|c|}{ 全体 } & \multicolumn{2}{|c|}{ 男子 } & \multicolumn{2}{|c|}{ 女子 } & \multicolumn{2}{|c|}{ 全体 } & \multicolumn{2}{|c|}{ 男子 } & \multicolumn{2}{|c|}{ 女子 } \\
\hline & .02 & (4) & -.01 & (4) & .04 & (4) & $-.08^{*}$ & (2) & $-.16^{* *}$ & (4) & .02 & (2) \\
\hline 非暴力ゲーム & .03 & (4) & -.01 & (4) & .08 & (4) & $.07^{*}$ & (2) & $.10^{*}$ & (2) & .03 & (2) \\
\hline
\end{tabular}

注：カッコ内は選択したモデルを示守。 * $p<.05, * * 0<.01$

表 9 行動からテレビゲーム変数への影響

\begin{tabular}{|c|c|c|c|c|c|c|c|c|c|c|c|c|}
\hline \multirow[b]{3}{*}{ 平日 } & \multicolumn{6}{|c|}{ 攻撃行動 } & \multicolumn{6}{|c|}{ 向社会的行動 } \\
\hline & \multicolumn{2}{|c|}{ 全体 } & \multicolumn{2}{|c|}{ 男子 } & \multicolumn{2}{|c|}{ 女子 } & \multicolumn{2}{|c|}{ 全体 } & \multicolumn{2}{|c|}{ 男子 } & \multicolumn{2}{|c|}{ 女子 } \\
\hline & .07 & (4) & .00 & (4) & .14 & (4) & .05 & (4) & -.00 & (4) & $.15^{\prime \prime}$ & (4) \\
\hline 土日 & .06 & (3) & .09 & (4) & .03 & (3) & -.06 & (2) & $-.10^{*}$ & (4) & .02 & (2) \\
\hline 1 週閒 & .03 & (3) & .06 & (3) & -.01 & (4) & -.04 & (2) & -.07 & (4) & .02 & (2) \\
\hline 暴カシーン & .05 & (1) & .02 & (1) & .11 & (1) & .05 & (2) & .10 & (4) & .04 & (4) \\
\hline 向社会的シーン & -.02 & (1) & -.05 & (3) & .01 & (2) & $.10^{*}$ & (2) & $.13^{*}$ & (2) & .09 & (1) \\
\hline 性的シーン & .03 & (1) & -.05 & (4) & .10 & (1) & .07 & (2) & .06 & (4) & .08 & (2) \\
\hline 暴力ゲーム & .07 & (4) & .10 & (4) & .06 & (4) & -.05 & (2) & -.02 & (4) & -.05 & (2) \\
\hline 非暴力ゲーム & -.03 & (4) & -.02 & (4) &. .05 & (4) & .02 & (2) & .05 & (2) & -.00 & (2) \\
\hline
\end{tabular}

注：カッコ内は選択したモデルを示す。 


\section{4. 考察}

本研究では、テレビゲーム使用の变数として、これ まで測定してきたテレビゲーム全体やジャンル別の使 用量に加え、新たにシーン別の接触量、さらに、ゲー ム嗜好という变数を测定し、テレビゲーム使用や暴力 シーン接触が子どもの攻撃行動㧍よび向社会的行動に 与える悪影響が存在するか否かを検討してきた。

結論から述べると、本研究の結果から、テレビゲー ム使用によって攻撃行動が促されるという悪影響は検 出されなかったが、男子の平日でのテレビゲーム使用 時間や、被調查者全体の暴力ゲーム暏好が向社会的行 動に負の影響をむたらしたという点では、悪影響の存 在が示唆された。な押、ゲームソフトの大部分には暴 カシーンが見られることから姐? 平日でのテレビゲー ム使用時間の影響は、暴力ンーンの影響にかなり重な るところがあると考えられる。

こ扎までの研究では、テレビゲーム使用とくに暴力 シーン接触が攻撃性を促すことはしばしば示されて招 り、筆者らの研究であそ机を確認する結果が得られて きた ${ }^{[9][103[18]}$ 。本研究の結果はそれと異なっているが、 一つ考えられるのは、テレビゲームの制作者側に㧍け る自主規制の影響である。例えば、1997年にCESA (コンピュータエンターテインメント協会）は、ゲー ムソフト表現に関する倫理規定を作成し、取り組みを 開始したが[2]、これなどの取り組みが進展するにつれ、 子ど屯が悪影響の生じやすい表現に接触することが少 なくなっているのかむしれない。

また、本研究の結果、政撃行動に対する悪影響は検 出されなかったものの、向社会的行動に対する悪影響 が検出されたが、このように、もともと攻撃行動に対 しては、悪影響は検出されにくいのかむしれない。攻 撃行動は、社会的規範から逸脱しており、仮にテレビ ゲーム使用によって攻撃傾向が高まっていたとしても、 それは直ちには攻撃行動として表出されず、その表出 にはむしろ攻撃行動が許容される場であるかどうか （例えば、悪さをした人を諌める）ということの影響 が大きいのかむし机ない。

あしそうであれば、このことはまた、テレビゲーム 使用や暴力シーン接触の影響を検討するときに、攻撃
性だけに注目するのでは、悪影響を小さく見積もり過 ぎて抢り、向社会性のような側面にも目を向けること が必要であることも示唆している。実際に、本研究だ けでなく、最近、暴力シーン接触によって向社会的行

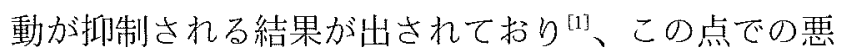
影響も注目されるものに思われる。

さて、本研究では、暴力シーンの悪影響と同時に、 被調查者全体や男子の向社会的シーンの接触および非 暴力的ゲーム嗜好が、向社会的行動を促すことが示唆 された。従来、テレビについて、暴力シーン接触が攻 撃行動を促す一方で、向社会的シーン接触が向社会的 行動を促すことが示されてきたが盟 [15]、テレビゲー ムでも向社会的シーン接触の好ましい影響がありうる ことが示されたと言える。これは、テレビゲーム使用 の影響があくまでもコンテンツ次第で、良いものにも 悪いあのにむなること、さらに言え壮、テレビゲーム が向社会性を増進する教育ッールにあなりえることを 示唆している。

また、向社会的シーン接触については、向社会的行 動がそれを促すという逆方向の影響す見出されており、 向社会的シーン接触と向社会的行動の間には、相乗的 に互いを促し合う関係があることも示唆された。

以上に述べてきたように、本研究は、テレビゲーム 使用や暴力ゲーム赀好が向社会的行動を抑制する一方 で、向社会的シーン接触がそ机を促すことを示唆して きた。今後は、これらの結果が小学生だけでなく、中 学生など他の年齢層であ得られるかどうか、また、本 研究では 2 回の調査の間隔を $2 \sim 4$ かんとしたが、異 なる間隔でも同様の結果が得られるかなど、結果の一 般性や特殊性についてさらに知見が蓄積されることが 望ましいと考元られる。

\section{文 献}

[1] Anderson,C. A.,Gentile, D. A., and Buckley, K. E., Violent Video Game Effects on Children and Adolescents: Theory, Research, and Public Policy, New York: Oxford University Press, 2007.

[2]坂元章,『テレビゲームと子どあの心一子ど屯た ちは凶暴化していくの加一』，メ夕モル出版， 2004

[3] Sakamoto, A., Video games and the psycho- 
logical development of Japanese children, I. Sigel (Series Ed.), D. W. Shwalb, J. Nakazawa, \& B. J. Shwalb (Vol. Eds.), Advances in Applied Developmental Psychology: Theory, Practice, and Research from Japan. Greenwich, CT: Informa-tion Age Publishing. pp.3-21, 2005.

[4] Anderson, C. A., An update on the effects of violent video games, Joumal of Adolescence, vol.27, pp.133-122. 2004.

[5] Anderson, C. A., and Bushman, B. J., Effects of violent videogames on aggressive behavior, aggressive cognition, aggressive affect, physiological arousal, and prosocial behavior: A meta-analytic review of the scientific literature, Psychological Science, vol.12, pp.353-359, 2001.

[6] Sherry, J.L., The effects of violent video games on aggression: A meta-analysis, Human Communication Research, vol.27, pp.409431, 2001.

[7] Finkel, S. E., Causal analysis with panel data. Thousand Oaks, CA: Sage, 1995.

[8]毛利瑞穂・坂元章・火八ロゆり汃・坂元桂・小林久 美子「テレビゲーム使用と攻撃性の因果関係の 検討一小学生に対するパネル研究一」『シミュ レーション\&ゲーミング』, 第11巻, pp.7-15, 2001.

[9] 井堀宣子・坂元章・小林久美子・木村文香「小 学生のテレビゲーム使用と攻撃性の因果関係に 関するパネル研究一身体的暴力に対する影響一」 『シミュレーション\&ゲーミング』，第13巻第 2 号, pp.139-148. 2003.

[10] Thori, N., Sakamoto, A., Kobayashi, K., and Kimura, F., Does video game use grow children's aggressiveness?: Results from a panel study. Proceedings of the 34 th Anmual Conference of the International Simulation and Gaming, pp.221-230, Chiba, Japan, 2003.

[11] Sakamoto, A., Video games and violence:
Controversy and research in Japan. C. von Feilitzen and U. Carlsson eds., Children in the new media landscape: Games, pornography, and perceptions. Goeteborg, Sweden: The UNESCO International Clearinghouse on Children and Violence on the Screen. pp.61-77, 2000.

[12] Shibuya, A., Sakamoto, A., Ihori, N., and Yukawa, S., The effects of the presence and contexts of video game violence on children: A longitudinal study in Japan, Simulation \& Gaming, in press.

[13] Wiegman, O. and van Schie, E. G. M., Video game playing and its relations with aggressive and prosocial behaviour, British Jounnal of Social Psychology, vol.37, pp.367-378. 1998.

[14] Friedrich, L. K. and Stein, A. H., Aggressive and prosocial television programs and the natural behavior of preschool children, Monographs of the Society for Research in Child Development, vol.38, pp.1-64, 1973.

[15] Ostrov, J. M., Gentile, D. A., and Crick, N. R., Media exposure, aggression and prosocial behavior during early childhood: A longitudinal study, Social Development, vol.15, pp.612627, 2006.

[16]桜井茂男「児童用社会的望ましさ測定尺度(SDS C) の作成」『教育心理学研究』，第32巻, pp.310314, 1984.

[17] Shibuya, A., and Sakamoto, A., The quantity and context of video game violence in Japan: Toward creating an ethical standard, R. Shiratori, K. Arai, \& F. Kato eds., Gaming, simulation and society: Research scope and perspective. Springer-Verlag. pp.111-120, 2005.

[18］坂元章・尾㥓恵・成島麗子・森津太子・坂元桂・ 高比良美詠子・伊部規子・鈴木佳苗・泉真由子 「テレビゲーム遊びが人間の暴力行動に及ばす影 響とその過程一女子大学生に対する2つの社会 心理学実験一」『シミュレーション\&ゲーミング』， 第11巻, pp.28-39, 2001. 


\title{
Effects of Video Games on Aggressive as well as Positive Social Behavior of Children - A Panel Study with Elementary School Students-
}

\author{
Nobuko IHORI ${ }^{\dagger}$ Akira SAKAMOTO Akiko SHIBUYA $^{\dagger \dagger}$ and Shintaro YUKAWA ${ }^{\ddagger}$ \\ ${ }^{\dagger}$ Graduate School of the Humanities and Sciences, Ochanomizu University \\ 2-1-1 Ohtsuka, Bunkyo-ku, Tokyo, 112-8610 Japan \\ ${ }^{\ddagger}$ Graduate School of the Humanities and Sciences, Ochanomizu University \\ 2-1-1 Ohtsuka, Bunkyo-ku, Tokyo, 112-8610 Japan \\ ${ }^{1}$ Institute for media and communications research, Keio University \\ 2-15-45 Mita, Minato-ku, Tokyo, 108-8345 Japan \\ $\mp$ Graduate School of Comprehensive Human Sciences, University of Tsukuba \\ 3-29-1 Ohtsuka, Bunkyo-ku, Tokyo, 112-0012 Japan \\ E-mail: †n_ihori07@hotmail.com
}

\begin{abstract}
We conducted a panel study with elementary school students in order to examine the effects of video games on children. We conducted two surveys, one measuring the amount children use video games, exposure to certain types of scenes, and preference for types of games, while the other measured the level of their aggressive behavior and positive social behavior. The result of cross-lagged effects model analysis suggested that boys' positive social behavior tended to be suppressed as they used video games more on weekdays. Also, for all the participants as a whole and for boys, their positive social behavior was promoted more as they were exposed to more positive social scenes, or they indicated stronger preference for non-violent games, while their positive social behavior was suppressed more as they indicated stronger preference for violent games.
\end{abstract}

Keywords Video Games, Aggressive Behavior, Positive Social Behavior, Panel Study 